"Sustainable Development Goals in agriculture and responsible investment: A comparative study of the Czech Republic and Ukraine"

\begin{tabular}{|c|c|}
\hline AUTHORS & $\begin{array}{l}\text { Alex Plastun (iD } \\
\mathbb{R} \\
\text { Inna Makarenko (iD) } \\
\mathbb{R} \\
\text { Tetiana Grabovska (i) } \\
\mathbb{R} \\
\text { Ricardo Situmeang } \\
\text { Serhii Bashlai (i) } \\
\mathbb{R}\end{array}$ \\
\hline ARTICLE INFO & $\begin{array}{l}\text { Alex Plastun, Inna Makarenko, Tetiana Grabovska, Ricardo Situmeang and } \\
\text { Serhii Bashlai (2021). Sustainable Development Goals in agriculture and } \\
\text { responsible investment: A comparative study of the Czech Republic and Ukraine. } \\
\text { Problems and Perspectives in Management, 19(2), 65-76. } \\
\text { doi:10.21511/ppm.19(2).2021.06 }\end{array}$ \\
\hline DOI & http://dx.doi.org/10.21511/ppm.19(2).2021.06 \\
\hline RELEASED ON & Thursday, 29 April 2021 \\
\hline RECEIVED ON & Sunday, 28 February 2021 \\
\hline ACCEPTED ON & Friday, 23 April 2021 \\
\hline LICENSE & $\begin{array}{l}(c) E Y \text { EY } \\
\text { This work is licensed under a Creative Commons Attribution } 4.0 \text { International } \\
\text { License }\end{array}$ \\
\hline JOURNAL & "Problems and Perspectives in Management" \\
\hline ISSN PRINT & $1727-7051$ \\
\hline ISSN ONLINE & $1810-5467$ \\
\hline PUBLISHER & LLC "Consulting Publishing Company "Business Perspectives" \\
\hline FOUNDER & LLC "Consulting Publishing Company "Business Perspectives" \\
\hline$\sigma^{\circ}$ & $\begin{array}{l}\text { ニニ } \\
\text { 三ニ }\end{array}$ \\
\hline NUMBER OF REFERENCES & NUMBER OF FIGURES \\
\hline 47 & 6 \\
\hline
\end{tabular}

(c) The author(s) 2021. This publication is an open access article. 


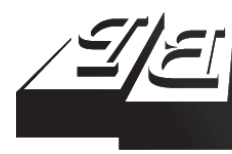

BUSINESS PERSPECTIVES

(O)

LLC "CPC "Business Perspectives"

Hryhorii Skovoroda lane, 10,

Sumy, 40022, Ukraine

www.businessperspectives.org

Received on: $28^{\text {th }}$ of February, 2021

Accepted on: $23^{\text {rd }}$ of April, 2021

Published on: $29^{\text {th }}$ of April, 2021

() Alex Plastun, Inna Makarenko, Tetiana Grabovska, Ricardo Situmeang, Serhii Bashlai, 2021

Alex Plastun, Doctor of Economics Professor, Chair of the Internationa Economic Relations Department, Sumy State University, Ukraine. (Corresponding author)

Inna Makarenko, Doctor of Economics, Associate Professor, Chair of the Accounting and Taxation Department, Sumy State University, Ukraine.

Tetiana Grabovska, Ph.D., Associate Professor, Department of General Ecology and Ecotrophology, Bila Tserkva National Agrarian University, Ukraine.

Ricardo Situmeang, Master of Art Ph.D. Student, Biogas Research Team, Faculty of Tropical AgriSciences, Czech University of Life Sciences, Czech Republic.

Serhii Bashlai, Ph.D., Associate Professor, Chair of Economics and Entrepreneurship, Sumy National Agrarian University, Ukraine.
Alex Plastun (Ukraine), Inna Makarenko (Ukraine), Tetiana Grabovska (Ukraine), Ricardo Situmeang (Czech Republic), Serhii Bashlai (Ukraine)

\section{SUSTAINABLE DEVELOPMENT GOALS IN AGRICULTURE AND RESPONSIBLE INVESTMENT: A COMPARATIVE STUDY OF THE CZECH REPUBLIC AND UKRAINE}

\begin{abstract}
This paper explores some Sustainable Development Goals (SDGs - 2 and 12) in agriculture for the Czech Republic and Ukraine. The idea is to find out best practices in implementing SDGs 2 and 12 within the responsible investment framework. For these purposes, benchmarking (comparative analysis) is used. Using data over the period of 2017-2020, a general comparative review of global and national targets of SDGs 2 and 12 in Ukraine and the Czech Republic is provided. The results justify the merely incorporation and compliance of these targets at the national and global levels. The identified problems in achieving SDG 2 and SDG 12 are common for Ukraine and the Czech Republic and relate to unequal access to investment and financial resources. Recommendations and solutions to the most important problems based on the responsible investment instruments are proposed in this paper. The research findings can be useful for regulators (both in agriculture and in the financial market), companies and a wide group of other stakeholders in promoting responsible investment to make more comprehensive progress towards SDG 2 and 12 in Czech Republic and Ukraine by 2030
\end{abstract}

Keywords

SDG, hunger, food security, investment, sustainable consumption, global targets, national targets, natural resources

JEL Classification $\quad$ M40, M41

\section{INTRODUCTION}

The UN Global Sustainable Development Goals 2 "End hunger, achieve food security and improved nutrition and promote sustainable agriculture" and "12 Ensure sustainable consumption and production patterns" (SDGs) are accelerating targets that contribute to the progress of other goals by 2030. Agriculture is a sector in which these SDGs can have a synergistic effect.

Achieving SDGs 2 and its targets is quite difficult even by 2050, since almost 800 million people in the world are chronically hungry, and 2 billion suffer from micronutrient deficiencies, and food production should increase by $60 \%$ (FAO, 2017a). Scientists also question that these targets will be reached by 2030 (Blesh et al., 2019).

The basis for ensuring progress for SDG 2 and 12, as well as for other SDGs is the formation of a sufficient pool of investment resources. The Addis Ababa Summit in 2015 is dedicated to finding mechanisms and investment tools for financing sustainable development and its Goals. 
The required amount to achieve the targets of these goals by 2030 by Food and Agriculture Organization (FAO), International Fund for Agricultural Development (IFAD) and World Food Program (WFP) is estimated at USD 265 billion a year by 2030 (Havemann et al., 2020). However, this amount does not cover the destructive impact on supply, production and consumption chains in the agro-industrial complex of the COVID-19 pandemic. This amount can be significantly increased. That is why, the development of investment tools for financing SDGs 2 and 12 in the agricultural sector on a responsible basis becomes particularly relevant.

The Czech Republic and Ukraine are different countries in terms of economic development in general and in the agro-industrial complex in particular. At the same time, both countries have recently joined the UN Global SDGs system and are taking the first steps in achieving them. The idea of this paper is to find common solutions in implementing SDGs 2 and 12 within the responsible investment framework based on the comparison of progress in SDG 2 and 12 in the agricultural sectors of the Czech Republic and Ukraine.

Using data from the Czech Republic and Ukraine over the period 2017-2020, a general comparative analysis of global and national targets of SDGs 2 and 12 in Ukraine and the Czech Republic is provided. The most crucial problems in achieving SDG 2 and SDG 12 are common for Ukraine and the Czech Republic. Typically, they are caused by a poor access to investment resources. The paper offers recommendations and solutions to the most important problems based on the responsible investment instruments.

\section{LITERATURE AND REGULATORY REVIEW}

In a competitive environment, it is difficult to put into practice environmental and other "irrational" principles that can only pay dividends in the distant future. In particular, this applies to small producers. They are increasingly looking for employment opportunities outside of agriculture. Therefore, it is necessary to focus on the role of small producers in agriculture, on the problems of their competitiveness and, at the same time, their more successful involvement in the process of implementing environmental imperatives in practice. This multidimensional goal covers three interrelated components: 1) ending hunger and improving nutrition (social dimension: $2.1,2.2), 2$ ) achieving food security by increasing productivity and increasing income (economic dimension: $2.3,2 . a$ ), and, to some extent, 2.b and 2.c; and 3) promoting sustainable agriculture (environmental measurement: 2.4 and 2.5) (Griggs et al., 2017; Mollier et al., 2017). SDG 2.3 offers a doubling of agricultural productivity and income for small farmers, which is extremely important, but does not take into account that large farmers may receive relatively low incomes from agriculture (Blesh et al., 2019). Domestic demand for basic food products is met by domestic production of up to $97-109 \%$, which corresponds to the optimistic level of food security recommended by FAO, and allows creating a solid basis for agricultural exports (Sustainable Development Goals Ukraine, 2020).

Achieving progress towards SDG 2 will depend on the progress made in meeting others from the 17 goals (FAO, 2016, 2017). However, interactions between SDGs currently have a weak conceptual and scientific basis. SDG 2 integrates and links food security, nutrition and sustainable and climate-resilient agriculture that does not adversely affect the climate system (Griggs et al., 2017). If there is a food shortage in the country as a result of climate change, achieving the SDG goal will be difficult (Mugambiwa \& Tirivangasi, 2017). SDG 12 and SDG 2 are related to smarter management of chemicals in terms of increasing production and more efficient use of natural resources. Although SDG 2 focuses more on final production and food outcomes, SDG 12 focuses on the procurement, processing and distribution of food, which provides a certain perspective of the food system (Griggs et al., 2017). Agricultural practices based on the specificities of each country and their priority are- 
as should be promoted, especially those contributing the achievement of several sustainability goals simultaneously (Gil et al., 2019).

In Ukraine, the main document governing compliance with the Sustainable Development Goals is the Decree of the President of Ukraine "On the Sustainable Development Goals of Ukraine until 2030". In total, 17 goals and 86 national tasks are incorporated in 145 normative legal acts of the Government, 1,052 tasks and 3,465 measures enshrined in these acts are aimed at the implementation of goals and tasks (Decree of President of Ukraine, 2019). The Government has established an Interagency Working Group on SDGs to coordinate efforts to achieve the goals. According to the 2019 results, Ukraine has generally made progress in 15 of the 17 SDGs. 86 targets and 172 national development indicators were identified (increased to 183) (Sustainable Development Goals Ukraine, 2020). The mechanism for monitoring the SDGs was institutionalized by adopting the order of the Cabinet of Ministers of Ukraine No. 686-r dated August 21, 2019 "Collection of data on monitoring the achievement of the SDGs". As part of the implementation of the State Program for the Development of Statistics for the period up to 2023, approved by the resolution of the Cabinet of Ministers of Ukraine No. 222 dated February 27, 2019, a special section on Sustainable Development Goals was created. The Ministry for the Development of Economic Trade and Agriculture of Ukraine (MDETA) initiated the creation of expert groups, in particular in the economic field (SDG 2, SDG 8, SDG 9, SDG 12).

The public vision of Ukraine's development until 2030 focuses on the well-being of the population, which will be provided by innovative economic development based on the sustainable use of natural resources. Moreover, economic growth will be based on the model of "green" economy (Pimonenko \& Lushchik, 2017), which can be achieved, in particular, through the intensification of socially responsible investment (IlchenkoSyuyva \& Slyusarchuk, 2019). The viability of investment in agriculture and food systems depends on well-functioning ecosystems and sustainable use of natural resources (FAO, 2014).

The Czech Republic adopted the Czech Republic's Voluntary National Review. It describes the im- plementation process of the 2030 Agenda and 17 SDGs within The Strategic Framework Czech Republic 2030 (this long-term process has started in July 2015). The implementation process includes national targets to be achieved by the 2030, as well as starting points in six key areas. The SDGs are classified as follows: the global, national and sub-national context. This will enable them to be successfully implemented in all relevant policies.

The implementation of specific SDGs targets is accompanied by changes in internal structure of the Czech Republic's ministries.

The second version of the Voluntary National Review draft evaluates the implementation SDGs targets and assesses target achievement in the Czech Republic. The results of the assessment are more optimistic than those from the previous analysis. The implementation of SDGs in the Czech Republic is still under threat without proper EU financial support. To reduce this risk, responsible investment can be used as a tool to achieve and support sustainable development. Intergovernmental and regional organizations play a key role in promoting responsible investment in agriculture and food systems (FAO, 2014).

According to FAO, International Fund for Agricultural Development (IFAD) and World Food Program (WFP), additional USD 265 billion a year are needed to reduce hunger by 2030 (Havemann et al., 2020). Eradicating poverty and hunger require USD 140 billion per year in agriculture and rural development. Up to $85 \%$ of that investment should be directed to African countries. These investments should be responsible, sustainable and benefit local communities, farmers and investors while adhering to environmental principles (FAO, 2019).

The starting point in determining how responsible investment in agriculture and food systems can contribute to food security and nutrition is the recognition and respect of human rights (according to CFS Principles for Responsible Investment in Agriculture and Food Systems - known as RAI). Another important issue is the use of mixed financing. It allows improving the risk/return ratio of investment by mixing capital flows with different expectations in the investment portfolio. In the situation of limited government budgets, this 
approach allows mobilizing more private sector's funding to support SDGs. For the case of agriculture, this means using public funding to enable private investors to invest without risk. For these purposes, national guarantee funds, subsidized lending, forced lending, and interest rate caps can be used.

Investments in agriculture require higher returns due to bigger risks and lower liquidity. Successful implementation of the SDGs needs the mobilization of significant private investment in sustainable agriculture. According to Havemann et al. (2020), a combination of public and private capital sources can increase the size of public investment and attractiveness of private capital (Havemann et al., 2020).

In 2017, Ukraine joined the Organization for Economic Cooperation and Development (OECD) on international investment and multinational enterprises and is implementing a policy of socially responsible business (Cabinet of Ministers of Ukraine, 2017, 2020). The Government has established an Interdepartmental Commission on Public Investment Projects. To simplify the procedure for attracting foreign investment, on May 31, 2016, the Law of Ukraine No. 1390-VIII "On Amendments to Certain Legislative Acts of Ukraine Concerning the Abolition of Mandatory State Registration of Foreign Investments" was adopted. On May 23, 2017, the Supreme Council of Ukraine adopted the Law of Ukraine "On Amendments to Certain Legislative Acts of Ukraine Concerning the Elimination of Barriers to Attracting Foreign Investments". On May 26, 2017, an Agreement on Investment Promotion and Protection was signed between Ukraine and the International Development Fund (Ministry for Development of Economy, Trade and Agriculture of Ukraine, 2021). It has been found that the influence of investors is geographically distributed as follows: $39 \%$ are investors headquartered in the United States and Canada, up to $25 \%$ - in Western, Northern and Southern Europe. The majority of investors in this sample are based on developed markets (72\%), almost half of the respondents invest more than $75 \%$ of their portfolio in emerging markets. About $42 \%$ of investors are focused on private capital, while $19 \%$ - on private debt and only $11 \%$ - on real assets (Hand et al., 2021).
The purpose of the study is to develop common possible solutions for regulators, countries, companies etc to the problem of introducing SDGs 2 and 12 and the financing problem within the framework for responsible investment.

\section{DATA AND METHODOLOGY}

A key method for comparing progress in achieving SDG 2 and 12 in the agricultural sector of Ukraine and the Czech Republic, as well as the role of responsible investment in this progress, is benchmarking (comparative analysis). The practical experience in implementing SDGs 2 and 12 is analyzed in the following dimensions:

- General comparative review of the compliance of global and national targets of SDGs 2 and 12 .

- The degree of target incorporation into the national policy.

- The progress of SDGs 2 and 12 at the level of Goals and Indicators according to global and national reviews.

- Problematic fields on the way to achieving SDGs 2 and 12 and prospects for its intensification.

Information and statistical sources are the basis for the comparative analysis (The Czech Republic's Voluntary National Review (2017), Sustainable Development Goals Ukraine. Voluntary National Review. (2020), abovementioned normative sources on SDGs and the database of Sachs et al. (2020).

\section{RESULTS}

Ukraine joined the Global SDGs system in 2017, forming national targets and progress indicators for each of them. SDGs 2 and 12 national targets' progress both in Ukraine and the Czech Republic do not fully take into account global targets and focus only on the most significant ones.

Simultaneously, such an essential target of SDG 2 , which connects responsible agriculture with re- 
sponsible investment mechanisms in its development, is overlooked in Ukraine. It is the target 2aIncrease investment, including through enhanced international cooperation, rural infrastructure, agricultural research and extension services, technology development and plant and livestock gene banks to enhance agricultural productive capacity in developing countries, particularly least developed countries".

Regarding SDG 12, it should be noted that Ukrainian national targets' system includes only $36 \%$ of global targets. They are related to reducing the national economy's resource intensity, lowering food losses in supply chains, sustainable use of chemicals and shortening waste formation. Targets that create information and analytical support for responsible investment at the national level (12.6 and 12.8) and the basis for responsible investment by authorities at all levels (12.7) were left out of consideration.

Czech Republic is ahead of or in line with the OECD average for every SDG including SDGs 2 and 12 . Protection of biodiversity and creation of favorable conditions for terrestrial ecosystems are close to the target levels. One of the key challenges for the case of SDG 12 is the implementation of appropriate measures to improve the management of wetlands and other natural bodies of water, and gradually revise certain agricultural and forest practices so as to prevent quick water runoff and soil erosion. An important issue for the case of achieving SDGs 2 and 12 in the Czech Republic is the development of urban areas and infrastructure in order to comply with the environmental standards and contribute to sustaining and strengthening ecosystem services.

The source of the SDGs system progress in Ukraine is the national system of legislation in strategic planning. As of 2020, it has 162 documents that cover 1,394 tasks, and they are specified in 4,296 measures to achieve all 17 SDGs. As for SDG 12, the number of tasks and activities has increased over the last two years, but it has decreased for SDG 2. At the same time, SDG 2 has a high integration level into state strategic documents, while SDG 12 has a medium level (Institute of SocioEconomic Research, 2017.)
Table 1. Incorporation of tasks for achieving SDGs 2 and 12 into state strategic documents

Source: Sustainable Development Goals Ukraine. Voluntary National Review (2020). State Statistics Service of Ukraine, Ministry for Development of Economy, Trade and Agriculture of Ukraine (2019).

\begin{tabular}{l|c:c:cc}
\hline \multirow{3}{*}{ Goal } & \multicolumn{4}{|c}{ Ukraine } \\
\cline { 2 - 5 } & \multicolumn{2}{|c}{$\mathbf{2 0 1 9}$} & $\mathbf{2 0 2 0}$ \\
\cline { 2 - 5 } & Tasks & Measures & Tasks & Measures \\
\hline SDG 2 & 52 & 66 & 44 & 48 \\
\hline SDG 12 & 47 & 230 & 59 & 283 \\
\hline
\end{tabular}

Despite the high and medium level of incorporation of the goals into the state strategic documents of Ukraine, the key challenge for their progress at the national policy level is the lack of responsible investments, primarily by the state. According to the World Bank and the IMF, responsible public investments, specified in the SDGs, can become a stimulus for responsible investment, if it is in line with the concept of "billion to trillion". It should be based on public-private partnerships and involve the "pay for success" mechanism, and the latest instruments for responsible investment (green, social bonds, impact investments, etc.).

In Ukraine, SDGs 2 and 12 are not integrated into the budget cycle and budget programming. Even the latest "Public Finance Management Strategy" does not contain guidelines for sustainable development or target indicators of SDG progress. Moreover, the specification of tasks and measures in the sectoral state strategic documents (Agrarian, Energy Strategies of Ukraine) is not linked to the relevant SDG targets and indicators. Thus, there is a significant gap between the formulation of tasks and measures for their progress and direct budget funding in the regulatory and legal support of SDG in Ukraine.

Also, no attention is paid to responsible investment. Responsible investment is defined in SDG 17 as the mobilization and allocation of external and internal investment resources and government and business partnership to ensure SDG progress. It is the next step, after the formation of a results-oriented budget (specific SDG), investing in SDG within a public and private partnership is possible, but only after the full SDG incorporation into the budget cycle at all levels.

From the side of the SDG 2, special attention needs to be paid to the development of investing mech- 
anisms in government support of the agricultural sector to raise food standards of the population. As for SDG 12, it is the investment mechanisms in the formation of less expensive production and distribution chains in the agro-industrial complex.

In the Czech Republic, responsible investment as defined in SDG 12 aims to maintain genetically diverse populations of native species and restoring natural habitats. For these purposes, grant aid both at European and national levels should be directed to support ecosystem services and achieve adequate food security.

Comparing the progress (Table 2 and 4 ) in achieving SDGs 2 and 12 in Ukraine within the national and the United Nations global reviews framework allows us to conclude the inconsistency of these monitoring data. Thus, according to the Voluntary National Review in 2019, Ukraine has advanced on 15 of the 17 Goals. In particular, out of 11 SDG 2 indicators that show progress, 7 have a positive trend; out of 5 SDG 12 indicators, the achievement of 3 is realistic by 2030 (Sustainable Development Goals Ukraine. Voluntary National Review. (2020).

At the same time, the data of global monitoring of these goals in Ukraine indicate a different trend and are not entirely consistent with the data of national monitoring.

The situation with SDG 12 is reversed. According to global monitoring, there are some existing chal- lenges to the achievement of SDG 12 in Ukraine. As a whole, its progress remains more significant compared to SDG 2. This might be related to incomplete data (there is a lack of data on target 2.3). The low level of waste processing in Ukraine, including post-harvest waste in the agro-industrial complex, casts doubt on this assessment.

As can be seen from Table 3, the progress in achieving the targets of SDGs 2 and 12 in the Czech Republic for the most cases is significant and has significant probability of achievement. The most problematic targets are 2.5 and 12.1. These aspects require additional attention because their achievement can be failed.

The existence of significant challenges in achieving the SDG 2 targets (Table 4) offsets the conclusions about their feasibility by 2030 .

Observing the progress for each indicator of SDGs 2 and 12 in Ukraine identified problem areas and prospects for overcoming these problems, in particular in terms of responsible investment, as well as indicators (Table 5).

Although the agro-industrial complex is a vital branch of the Ukrainian economy and its exports (44.3\% of exports of goods in 2019), and there is a growth in capital investment and modernization in this area (increase in investment by 2 times over the past five years), the achievement of initial targets of SDG 2 is hardly realistic. First of all, there

Table 2. Assessment of progress in achieving the targets of SDGs 2 and 12 in Ukraine based on national monitoring data

Source: Sustainable Development Goals Ukraine. Voluntary National Review (2020).

\begin{tabular}{|c|c|c|c|}
\hline $\begin{array}{l}\text { Dynamics of indicators } \\
\text { by targets }\end{array}$ & Characteristics of progress & SDG 2 & SDG 12 \\
\hline \multirow{2}{*}{ Almost unfulfilling } & \multirow{2}{*}{$\begin{array}{l}<20 \% \text { cannot be achieved with such dynamics (it is not achievable until } \\
2020 \text { ) }\end{array}$} & 2.1 .2 & 12.4 .1 \\
\hline & & 2.3 .3 & 12.4 .2 \\
\hline Low probability of achievement & $20 \% \leq$ and $<60 \%$ needs significant acceleration & 2.1 .1 & - \\
\hline Medium probability of achievement & $60 \% \leq$ and $<80 \%$ needs some acceleration & 2.3 .2 & - \\
\hline \multirow{7}{*}{ High probability of achievement } & \multirow{7}{*}{$\geq 80 \%$ on the way to achievement } & 2.1 .3 & 12.1 \\
\hline & & 2.1 .4 & 12.2 .1 \\
\hline & & 2.1 .5 & \multirow{5}{*}{12.2 .2} \\
\hline & & 2.2 .1 & \\
\hline & & 2.2 .2 & \\
\hline & & 2.3 .1 & \\
\hline & & 2.4 .1 & \\
\hline
\end{tabular}

Note: Data for 12.3 is not available. 
Table 3. Assessment of progress in achieving the targets of SDGs 2 and 12 in the Czech Republic based on national monitoring data

Source: Sustainable Development Goals Czech Republic. Voluntary National Review (2020).

\begin{tabular}{|c|c|c|c|}
\hline $\begin{array}{l}\text { Dynamics of indicators } \\
\text { by targets }\end{array}$ & Characteristics of progress & SDG 2 & SDG 12 \\
\hline Almost unfulfilling & $\begin{array}{l}<20 \% \text { cannot be achieved with such dynamics (it is not achievable } \\
\text { until 2020) }\end{array}$ & 2.5 & 12.1 \\
\hline Low probability of achievement & $20 \% \leq$ and $<60 \%$ needs significant acceleration & $2.5 . b$ & 12.212 .3 \\
\hline $\begin{array}{l}\text { Medium probability of } \\
\text { achievement }\end{array}$ & $60 \% \leq$ and $<80 \%$ needs some acceleration & 2.5.a 2.5 c 2.5.d & 12.412 .5 \\
\hline \multirow{5}{*}{ High probability of achievement } & \multirow{5}{*}{$\geq 80 \%$ on the way to achievement } & 2.1 & 12.6 \\
\hline & & 2.2 & 12.6.a \\
\hline & & 2.3 & 12.6.b \\
\hline & & 2.4 & \multirow{2}{*}{ 12.6.c } \\
\hline & & $2.5 . b$ & \\
\hline
\end{tabular}

Table 4. Assessment of progress in achieving the targets of SDGs 2 and 12 in Ukraine and the Czech Republic according to global monitoring

Source: Sachs et al. (2020).

\begin{tabular}{|c|c|c|c|c|c|c|c|c|}
\hline \multirow{2}{*}{ Country } & \multirow{2}{*}{$\begin{array}{l}2020 \text { SDG } \\
\text { Index Score }\end{array}$} & \multirow{2}{*}{$\begin{array}{l}2020 \text { SDG } \\
\text { Index Rank }\end{array}$} & \multicolumn{3}{|c|}{ SDG 2} & \multicolumn{3}{|c|}{ SDG 12} \\
\hline & & & Score & Status & Trend & Score & Status & Trend \\
\hline Czech Republic & 80,58 & 8 & 94,09 & $\begin{array}{l}\text { Significant } \\
\text { challenge }\end{array}$ & 入 & 70,39 & $\begin{array}{l}\text { Significant } \\
\text { challenge }\end{array}$ & - \\
\hline Ukraine & 74,24 & 47 & 91,73 & $\begin{array}{l}\text { Significant } \\
\text { challenge }\end{array}$ & ス & 64,78 & Challenges remain & - \\
\hline
\end{tabular}

is a problem with the low level of food security and purchasing power of households in Ukraine, associated with farmers' unequal access to investment resources. Also, there is a lack of food standards; deformation of the agro-industrial complex structure with the predominance of raw material industries with less added-value than the processing industries and the disordered sphere of organic agriculture and production.

The state should formulate the basic principles of responsible investment to intensify progress in achieving SDG 2 targets within the strategy of government support for agriculture, clustering and cooperation of rural areas, and effective use of public-private partnership investment mechanisms with providing transparency and anti-corruption policy.

The significant waste intensity of Ukraine's GDP and the increase in the amount of waste generated compared to the volume of utilized (less than a third) remains extremely problematic in case of SDG 12 (up to $104 \%$ in 2018). The solution to overcoming these problems might be the formation of investment incentives for Ukrainian companies' environmentally friendly activities, improving the legislation in waste management and recycling, and the transition of the economy to a circular basis.

Overall, in most cases, SDG-2 and 12 in the Czech Republic are ready for their implementation, or have been partially implemented. More detailed information regarding the progress in SDGs should be provided in the first official report on the implementation of the 2030 Agenda. But it was delayed due to the COVID-19 state of emergency. This report should serve as a basis for the second Voluntary National Review (VNR) planned for 2021.

As for the challenges, the main problem is the lack of attention from government authorities to the Sustainable Development issues. Other problems related to the progress in achieving SDGs 2 and 12 in the Czech Republic are presented in Table 6. 
Table 5. Problems arising in the process of achieving SDGs 2 and 12 in Ukraine, and solutions to come up with them

Source: Author's development.

\begin{tabular}{|c|c|c|}
\hline Target & Problem & Solution \\
\hline \multicolumn{3}{|c|}{ SDG 2} \\
\hline $\begin{array}{l}\text { 2.1.2. Consumption of milk and } \\
\text { dairy products per capita, } \mathrm{kg} / \text { year }\end{array}$ & \multirow[t]{2}{*}{$\begin{array}{l}\text { Low level of food security and } \\
\text { purchasing power of the population }\end{array}$} & \multirow[t]{2}{*}{$\begin{array}{l}\text { Providing microcredit to SMEs in the agriculture field to } \\
\text { diversify the market and reduce the production cost }\end{array}$} \\
\hline $\begin{array}{l}\text { 2.1.1. Consumption of meat per } \\
\text { capita, } \mathrm{kg} / \text { year }\end{array}$ & & \\
\hline $\begin{array}{l}\text { 2.3.2. Share of the food industry } \\
\text { and agricultural raw materials } \\
\text { processing production in exports } \\
\text { of UCGFEA groups } 1-24, \%\end{array}$ & $\begin{array}{l}\text { Low share of value-added of } \\
\text { agricultural processing production in } \\
\text { distribution chains }\end{array}$ & $\begin{array}{l}\text { Using investment tools of a public-private partnership to } \\
\text { support agricultural processing companies }\end{array}$ \\
\hline $\begin{array}{l}\text { 2.3.3. Share of agricultural land } \\
\text { under organic production in the } \\
\text { total area of agricultural lands of } \\
\text { Ukraine, \%* }\end{array}$ & $\begin{array}{l}\text { Inconsistency of the legislation on the } \\
\text { regulation of organic production and } \\
\text { the formation of its market }\end{array}$ & $\begin{array}{l}\text { The incentive of responsible investments in organic } \\
\text { production, taking into account environmental factors } \\
\text { of agricultural companies screening, completion of } \\
\text { the formation of operational (markers, benchmarks, } \\
\text { circulation technologies) and regulatory infrastructure of } \\
\text { this market }\end{array}$ \\
\hline \multicolumn{3}{|c|}{ SDG 12} \\
\hline $\begin{array}{l}\text { 12.4.1. Volume of waste generated } \\
\text { by all economic activities per unit } \\
\text { of GDP, kg per USD1,000 PPP in } \\
2011\end{array}$ & $\begin{array}{l}\text { Significant wear of production capacity } \\
\text { in energy, metallurgy, which cause high } \\
\text { carbon content of products, lack of real } \\
\text { data on waste }\end{array}$ & $\begin{array}{l}\text { Mandatory reporting on companies' environmental } \\
\text { criteria; attracting investment in the modernization } \\
\text { of production capacities, the formation of investment } \\
\text { incentives for such modernization and the developing of } \\
\text { low-waste technologies }\end{array}$ \\
\hline $\begin{array}{l}\text { 12.4.2. Share of burned and } \\
\text { recycled waste in the total waste } \\
\text { generated, \% }\end{array}$ & $\begin{array}{l}\text { Lack of waste disposal capacity, low } \\
\text { share of recycling processes in all } \\
\text { sectors of the economy, including raw } \\
\text { materials (agro-industrial complex, } \\
\text { metallurgy) }\end{array}$ & $\begin{array}{l}\text { Increasing the companies' investment attractiveness in } \\
\text { the field of waste processing within the state investment } \\
\text { policy; investment resources allocation in the circular } \\
\text { economy technology; raising consumers' environmental } \\
\text { awareness }\end{array}$ \\
\hline
\end{tabular}

Table 6. Problems arising in the process of achieving SDGs 12 in the Czech Republic, and solutions to come up with them

Source: SDG Watched Europe (2020), Strategic Framework Czech Republic 2030 (2020).

\begin{tabular}{|c|c|c|}
\hline Target & Problem & Solution \\
\hline \multicolumn{3}{|c|}{ SDG 12} \\
\hline $\begin{array}{l}\text { Priority 1. Landscape conservation } \\
\text { as a prerequisite for biodiversity } \\
\text { conservation }\end{array}$ & $\begin{array}{l}\text { 1. The current condition of the landscape } \\
\text { and biodiversity is not satisfactory: } \\
\text { landscape is exposed to the inadequate } \\
\text { intensification of agricultural and forestry } \\
\text { production, and excessive and inappropriate } \\
\text { urbanization }\end{array}$ & $\begin{array}{l}\text { 1. Planting of hedgerows, tree lines, solitary trees, } \\
\text { windbreaks, water elements and territorial systems } \\
\text { of ecological stability to prevent the landscape's } \\
\text { ecological stability disruption }\end{array}$ \\
\hline $\begin{array}{l}\text { Objective 1.1: Maintaining and } \\
\text { enhancing the ecological stability } \\
\text { of the landscape and supporting } \\
\text { its functions, especially through } \\
\text { sustainable landscape management }\end{array}$ & $\begin{array}{l}\text { 2. The absence of suitable living conditions } \\
\text { for wild species of flora and fauna in } \\
\text { landscape is a threat to biodiversity }\end{array}$ & $\begin{array}{l}\text { 2. Promotion of construction within or with } \\
\text { links to existing settlements, promotion of the } \\
\text { use of brownfields, minimization of ecosystem } \\
\text { fragmentation }\end{array}$ \\
\hline \multirow[t]{2}{*}{$\begin{array}{l}\text { Objective 1.2: Conserving the open } \\
\text { landscape } \\
\text { Objective } 3 \text { : Halting the decline in } \\
\text { biodiversity }\end{array}$} & \multirow{2}{*}{$\begin{array}{l}\text { 3. High percentage of arable land, erosion } \\
\text { and degradation risks (both chemical } \\
\text { and biological), the use of fertilizers and } \\
\text { pesticides, excessive hunting makes } \\
\text { development of agro-ecosystems } \\
\text { disproportional }\end{array}$} & $\begin{array}{l}\text { 3. Protection of surviving sites with natural } \\
\text { communities and land management based on } \\
\text { the needs of specially protected and endangered } \\
\text { species and specific communities }\end{array}$ \\
\hline & & $\begin{array}{l}\text { 4. Implementation of rescue program for the } \\
\text { most critically endangered species of flora and } \\
\text { fauna; restriction of new invasive species and } \\
\text { the expansion of those already present based on } \\
\text { appropriate legislative and financial mechanisms }\end{array}$ \\
\hline $\begin{array}{l}\text { Priority 2. Responsible farming and } \\
\text { forestry }\end{array}$ & $\begin{array}{l}\text { 1. Intensive farming has disturbed landscape } \\
\text { water regime, caused water pollution and } \\
\text { soil degradation, decreased biodiversity and } \\
\text { reduced ecological stability of the landscape }\end{array}$ & $\begin{array}{l}\text { 1. Preservation of genetic resources, including } \\
\text { agricultural crops, trees and animals }\end{array}$ \\
\hline
\end{tabular}


Table 6 (cont.). Problems arising in the process of achieving SDGs 12 in the Czech Republic, and solutions to come up with them

\begin{tabular}{|c|c|c|}
\hline Target & Problem & Solution \\
\hline \multicolumn{3}{|c|}{ SDG 12} \\
\hline $\begin{array}{l}\text { Objective 1: Promoting sound and } \\
\text { close-to-nature farming methods } \\
\text { and developing the non-production } \\
\text { functions of farming }\end{array}$ & $\begin{array}{l}\text { 2. Agro-ecosystems in production areas } \\
\text { are characterized by a high percentage of } \\
\text { arable land, erosion and degradation risks } \\
\text { (both chemical and biological), the use of } \\
\text { fertilizers and pesticides, excessive hunting } \\
\text { etc }\end{array}$ & $\begin{array}{l}\text { 2. Increasing the proportion of natural regeneration, } \\
\text { promotion of biological diversity in forests }\end{array}$ \\
\hline \multirow{2}{*}{$\begin{array}{l}\text { Objective 2: Conserving and } \\
\text { enhancing biological diversity in } \\
\text { forests through promoting sound, } \\
\text { close-to-nature farming methods } \\
\text { in forests and reinforcing the non- } \\
\text { production functions of forest } \\
\text { ecosystems }\end{array}$} & \multirow{2}{*}{$\begin{array}{l}\text { 3. The loss of natural fertility, a significant } \\
\text { reduction in water retention capacity, } \\
\text { reduced biodiversity and declining } \\
\text { populations of native species caused by the } \\
\text { changes in the forest ecosystems }\end{array}$} & $\begin{array}{l}\text { 3. Promotion of closer-to-nature management } \\
\text { that is based on the maximum utilization of natural } \\
\text { processes }\end{array}$ \\
\hline & & $\begin{array}{l}\text { 4. Replacement of the original forests (have low } \\
\text { ecological stability and an unsuitable species, age } \\
\text { and spatial composition) with conifer monocultures }\end{array}$ \\
\hline $\begin{array}{l}\text { Priority } 3 \text {. Adaptation to climate } \\
\text { change }\end{array}$ & $\begin{array}{l}\text { Floods pose serious direct risk for the } \\
\text { Czech Republic because of substantial } \\
\text { material damage, life losses, damage to } \\
\text { the landscape and ecology in general. The } \\
\text { reasons for this high vulnerability include } \\
\text { inappropriate urbanization and construction } \\
\text { in floodplains. }\end{array}$ & $\begin{array}{l}\text { Implementation of close-to-nature and technical } \\
\text { flood-control measures (natural overflows, dry } \\
\text { polders, etc.) while also ensuring that these } \\
\text { measures help achieve a maximum improvement of } \\
\text { the landscape water regime }\end{array}$ \\
\hline $\begin{array}{l}\text { Objective 1: Ensuring readiness to } \\
\text { deal with emergencies related to } \\
\text { climate change }\end{array}$ & \multirow{4}{*}{$\begin{array}{l}\text { Increasing temperatures might cause dry } \\
\text { periods in some agricultural areas. The } \\
\text { problem is deepening because of the drying } \\
\text { of surface and subsurface water }\end{array}$} & \multirow{4}{*}{$\begin{array}{l}\text { Implementation of retention elements both } \\
\text { technical (reservoirs and polders) and natural or } \\
\text { close-to-nature (wetlands, pools, floodplain forests) } \\
\text { will help to retain rainwater in the landscape, and to } \\
\text { revitalize the existing retention elements including } \\
\text { the floodplains of watercourses and their natural } \\
\text { overflows }\end{array}$} \\
\hline $\begin{array}{l}\text { Objective 2: Achieving a good } \\
\text { quantitative condition of } \\
\text { groundwater and surface water }\end{array}$ & & \\
\hline $\begin{array}{l}\text { Objective } 3: \text { Improving the water } \\
\text { regime in the landscape }\end{array}$ & & \\
\hline $\begin{array}{l}\text { Objective 4: Reducing the impacts } \\
\text { of expected global climate change } \\
\text { and extreme weather events on } \\
\text { forest and agricultural ecosystems }\end{array}$ & & \\
\hline
\end{tabular}

\section{CONCLUSION}

An overall comparative review of global and national targets of SDGs 2 and 12 in Ukraine and the Czech Republic justifies simply including and adhering to these targets at the national and global levels. Some tasks are skipped in both countries. There is also inconsistency between data of global monitoring of these goals in Ukraine and the Czech Republic. This inconsistency, in the absence of some SDG tracking data, does not provide a real picture of progress in both countries.

The identified problems in achieving SDG 2 and SDG 12 are common for Ukraine and the Czech Republic and relate to the gap between SDGs tasks and their investment farmers' unequal access to investment resources, effective use of public-private partnership investment mechanisms with providing transparency.

Eliminating a gap in funding for SDGs 2 and 12 is relevant for both developed countries (the Czech Republic) and developing countries (Ukraine). The same challenges arise for these countries in achieving the SDG targets by 2030, comparing their progress and tools of responsible investment aimed at intensifying such progress.

Common possible ways to solve the problems of SDGs 2 and 12 implementation include the alignment of the system of national and global targets of SDG 2 and 12 in Ukraine and the Czech Republic to ensure their full coverage; deepening the system of monitoring targets, tasks and indicators for the studied 
goals in both countries (vertical approach); expanding the range of stakeholders to contribute to reporting, tracking and progress towards these goals (horizontal approach); inclusion in national budget cycles, programs and strategies for the development of the agricultural sector of the SDGs - focused budgeting and coverage of all targets and tasks of the SDG 2 and 12; creating a common base of the most effective responsible investment tools at the level of the Ministry of Economic Development, Trade and Agriculture of Ukraine and The Office of the Government and the Ministry of Environment Czech Republic, as well as financial market regulators for both countries to provide sufficient investment resources of SDGs 2 and 12. Among them are private-public partnership, impact investment, microcredit; encouraging responsible behavior of producers and consumers of agro-industrial products in order to create better value along supply chains; strengthening the investment attractiveness and transparency of companies on the principles of a circular economy.

\section{AUTHOR CONTRIBUTIONS}

Conceptualization: Alex Plastun, Inna Makarenko, Tetiana Grabovska.

Data curation: Tetiana Grabovska, Ricardo Situmeang.

Formal analysis: Serhii Bashlai.

Funding acquisition: Alex Plastun, Inna Makarenko, Tetiana Grabovska, Ricardo Situmeang, Serhii Bashlai.

Investigation: Inna Makarenko, Tetiana Grabovska, Ricardo Situmeang.

Methodology: Alex Plastun, Inna Makarenko.

Project administration: Alex Plastun.

Resources: Tetiana Grabovska.

Software: Ricardo Situmeang.

Supervision: Alex Plastun.

Validation: Inna Makarenko.

Visualization: Ricardo Situmeang.

Writing - original draft: Alex Plastun, Inna Makarenko, Tetiana Grabovska, Ricardo Situmeang, Serhii Bashlai.

Writing - review \& editing: Alex Plastun, Inna Makarenko, Tetiana Grabovska, Ricardo Situmeang, Serhii Bashlai.

\section{ACKNOWLEDGMENT}

Authors are grateful to the Czech government for the support provided by the Ministry of Foreign Affairs of the Czech Republic, which allowed this scientific cooperation to start within the project "AgriSciences Platform for Scientific Enhancement of HEIs in Ukraine".

\section{REFERENCES}

1. Bass, R., Sunderji, S., Nova, N., \& Hand, D. (2020). Understanding Impact Performance: Agriculture Investments. Global Impact Investing Network. The GIIN. Retrieved from https://thegiin.org/ research/publication/understanding-impact-performance

2. Blesh, J., Hoey, L., Jones, D., Friedmann, A., \& Perfecto, I. (2019). Development pathways toward "zero hunger". World Harriet
Development, 118, 1-14. https://doi. org/10.1016/j.worlddev.2019.02.004

3. Cabinet of Ministers of Ukraine. (n.d.). Order № 66-r Kyiv dated January 24, 2020 "On approval of the Concept of implementation of state policy in the field of promoting socially responsible business in Ukraine for the period up to 2030". (In Ukrainian). Retrieved from https://zakon.rada.gov.ua/laws/ show/66-2020-\%D1\%80\#Text
4. Cabinet of Ministers of Ukraine. (n.d.a). Order dated March 1, 2017 № 130-r Kyiv “On signing an Agreement (in the form of an exchange of letters) between the Government of Ukraine and the Organization for Economic Cooperation and Development on accession to the Declaration on International Investment and Multinational Enterprises Organizations of economic 
cooperation and development". (In Ukrainian). Retrieved from https:// www.kmu.gov.ua/npas/249792424

5. Czech Republic, Implementation Plan for the Strategic Framework Czech Republic 2030, Prague 2018. Retrieved from https://sustainabledevelopment.un.org/content/ documents/15717Czech_Republic. pdf

6. Czech Republic, Strategic Framework Czech Republic 2030, Office of the Government of the Czech Republic, Department of Sustainable Development, Prague 2017. Retrieved from https://sustainabledevelopment.un.org/index. php? page $=$ view $\& n r=1562 \&$ type $=50$ $4 \&$ menu $=139$

7. Decree of the President of Ukraine on the Sustainable Development Goals of Ukraine until 2030. Kyiv, September 30, 2019 № 722/2019. (In Ukrainian). Retrieved from https://zakon.rada.gov.ua/laws/ show/722/2019\#Text

8. FAO. (2014). Principles for Responsible Investment in Agriculture and Food Systems. The Committee on World Food Security (CFS). Retrieved from http://www. fao.org/3/a-au866e.pdf

9. FAO. (2016). Food and agriculture Key to achieving the 2030 Agenda for Sustainable Development. Retrieved from https://sustainabledevelopment.un.org/content/documents/23 13foodandagriculture.pdf

10. FAO. (2017). The future of food and agriculture - Trends and challenges. Rome. Retrieved from http://www. fao.org/policy-support/tools-andpublications/resources-details/ en/c/472484/

11. FAO. (2017a). Supporting responsible investments in agriculture and food systems. Overview of the FAO Umbrella Programme (12 p.) Rome. Retrieved from http://www.fao.org/ in-action/responsible-agriculturalinvestments/en/

12. FAO. (2019). Supporting Responsible Investments in Agriculture and Food Systems (RAI). International Conference on Responsible Agricultural Investment to Achieve the Sustainable Development Goals by 2030.
Retrieved from http://www.fao. org/in-action/responsible-agricultural-investments/news/detail/ en/c/1238982/

13. Gil, J. D. B., Reidsma, P., Giller, K., Todman L., Whitmore, A., \& van Ittersum, M. (2019). Sustainable development goal 2: Improved targets and indicators for agriculture and food security. Ambio, 48, 685-698. https://doi.org/10.1007/ s13280-018-1101-4

14. Griggs, D., Nilsson, M., McCollum, D., \& Stevance, A-S. (2017). A Guide to SDG Interactions: from Science to Implementation (239 p.). Paris: International Council for Science. Retrieved from https://council. science/publications/a-guide-tosdg-interactions-from-science-toimplementation/

15. Hand, D., Sunderji, S., Nova, N., \& De I. (2021). Impact investing decision-making: Insights on financial performance. Global Impact Investing Network. Retrieved from https://thegiin.org/research/ publication/impact-investing-decision-making-insights-on-financialperformance

16. Havemann, T., Negra, C., \& Werneck, F. (2020). Blended finance for agriculture: exploring the constraints and possibilities of combining financial instruments for sustainable transitions. Agriculture and Human Values, 37, 1281-1292 https://doi.org/10.1007/s10460-02010131-8

17. Ilchenko-Syuyva, L.V., \& Slyusarchuk, O. P. (2019). Socially responsible investment activity as a factor of sustainable development. Investments: Practice and Experience, 10, 109-114. http://dx.doi. org/10.1007/978-3-319-639512 301-1

18. Institute of Socio-Economic Research. (2017). Analysis of state strategic documents of Ukraine to take into account the Sustainable Development Goals for 2030 adapted for Ukraine (84 p.). (In Ukrainian). Retrieved from https:// www.ua.undp.org/content/dam/ ukraine/docs/SDGreports/\%D0\%A 0\%D0\%B5\%D0\%B7\%D1\%8E\%D 0\%BC\%D0\%B5\%20RIA_\%D1\%83\%D0\%BA\%D1\%80_270917.pdf
19. Kolesnyk, T., Samborska, O., Talavyria, M., \& Nikolenko, L. (2018). Ensuring the sustainable development of the Ukrainianagrarian sector in conditions of globalization. Problems and Perspectives in Management, 16(3), 245258. https://doi.org/10.21511/ ppm.16(3).2018.20

20. McNeill D. (2019). The Contested Discourse of Sustainable Agriculture. Glob Policy, 10, 16-27. https://doi.org/10.1111/17585899.12603

21. Ministry for Development of Economy, Trade and Agriculture of Ukraine. (2021). The state of investment activity in Ukraine. Retrieved from https://www.me.gov. ua/

22. Ministry of Foreign Affairs of the Czech Republic. (2017) Development Cooperation Strategy of the Czech Republic 2018-2030. Prague. Retrieved from https://www. mzv.cz/jnp/en/foreign_relations/ development_cooperation_and_humanitarian/development_cooperation_strategy_of_the_1.html

23. Mollier, L., Seyler, F., Chotte, J-L., \& Ringler, C. (2017). End hunger, achieve food security and improved nutrition and promote sustainable agriculture: SDG 2. Stevance A. S. (coord.). A guide to SDG interactions: from science to implementation [SDG: Sustainable Development Goals]. ICSU, 31-80. Retrieved from https:// www.ifpri.org/publication/endhunger-achieve-food-security-andimproved-nutrition-and-promotesustainable

24. Mugambiwa, S. S., \& Tirivangasi, H. M. (2017). Climate change: A threat towards achieving 'Sustainable Development Goal number two' (end hunger, achieve food security and improved nutrition and promote sustainable agriculture) in South Africa. Jàmbá: Journal of Disaster Risk Studies, 9(1), 1-6. https://dx.doi.org/10.4102/jamba. v9i1.350

25. OECD. (2017, July 18). Getting Governments Organised to Deliver on the Sustainable Development Goals. High Level Political Forum 
United Nations. New York. Retrieved from https://www.oecd. org/gov/SDGs-Summary-ReportWEB.pdf

26. OECD. (2017, October 26-27). Decision making in an environment of uncertainty and change. Meeting of Senior Officials from Centres of Government. Retrieved from https://www.oecd.org/gov/cog2017-session-notes-web.pdf

27. OECD. (n.d.). Measuring Distance to the SDG Targets, OECD 2019. Retrieved from https://www.oecd. $\mathrm{org} / \mathrm{sdd} /$ measuring-distance-to-thesdgs-targets.htm

28. Petrushenko, Y., Aleksandrov, V., Vorontsova, A., \& Ponomarenko, O. (2020). Sustainable development goals as a tool for strategic planning in communities: a bibliometric analysis of research (E3S Web of Conferences, №202 (03005)). https://doi.org/10.1051/e3sconf/202020203005

29. Pimonenko, T. V., \& Lushchik, K. V. (2017). Green investing: the EU experience for Ukraine. Bulletin of Sumy State University. Economics series, 4, 121-127. (In Ukrainian). Retrieved from https://essuir.sumdu. edu.ua/handle/123456789/68437

30. Rosegrant, M. W., Koo, J., Cenacchi, N., Ringler, C., Robertson, R., Fisher, M., Cox, C., Garrett, K., Perez, N. D., \& Sabbagh P. (2014). Food Security in a World of Natural Resource Scarcity: The role of agricultural technologies (International Food Policy Research Institute: Washington, USA. 250 p.). http:// dx.doi.org/10.2499/9780896298477

31. Sachs, J., Schmidt-Traub, G., Kroll, C., Lafortune, G., Fuller, G., \& Woelm, F. (2020). The Sustainable Development Goals and COVID-19. Sustainable Development Report 2020. Cambridge: Cambridge University Press. Retrieved from https://s3.amazonaws.com/sustainabledevelopment.report/2020/2020 sustainable_development_report. pdf

32. Saravanakumar, V., Malaiarasan, U., \& Balasubramanian, R. (2020). Sustainable Agriculture, Poverty, Food Security and Improved Nutrition. In S. Hazra \& A. Bhukta (Eds), Sustainable Development
Goals. Sustainable Development Goals Series. Springer, Cham. https://doi.org/10.1007/978-3-03042488-6_2

33. Savitska, S., Zaika, S., Svystun, L., Koval, L., \& Haibura, Yu. (2020). Investment providing sustainable development of rural areas in Ukraine. Independent Journal of Management \& Production, Special Edition ISE, S\&P, 11(8), 571-586. https://doi.org/10.14807/ijmp. v11i8.1218

34. SDG in Ukraine. (2021). SDG 2. Retrieved from https://www. ua.undp.org/content/ukraine/uk/ home/sustainable-developmentgoals/goal-2-zero-hunger.html

35. SDG in Ukraine. (2021a). SDG 12. Retrieved from https://www. ua.undp.org/content/ukraine/uk/ home/sustainable-developmentgoals/goal-12-responsible-consumption-and-production.html

36. Shkura, I. S. (2016). The role of socially responsible investment in ensuring sustainable development of Ukraine. Economic Nobel Herald, 1(9), 252-262. pdf (In Ukrainian). http://ir.duan.edu. ua/bitstream/123456789/836/1/ bmef_2016_1_30.

37. Sokil, O., Zhuk, V., \& Vasa, L. (2018). Integral assessment of the sustainable development of agriculture in Ukraine. Economic Annals-XXI, 170(3-4), 15-21. Retrieved from http://elar.tsatu.edu. ua/handle/123456789/6500

38. State Statistics Service of Ukraine, Ministry for Development of Economy, Trade and Agriculture of Ukraine. (2019). Monitoring Report "Sustainable Development Goals in Ukraine". (In Ukrainian). Retrieved from http://www.ukrstat.gov.ua/csr_ prezent/ukr/st_rozv/publ/SDGsMonitoringReport_v08_24.09.2019. pdf

39. Stehnei, M., Irtysheva, I., Boiko, Ye., \& Khaustova, K. (2019). Strategic Priorities and Effectiveness of the Implementation of the State Policy for Sustainable Agricultural Development in Ukraine. Public policy and administration, 18(2), 194-208. https://doi.org/10.13165/ VPA-19-18-2-02
40. Stukalo, N., Lytvin, M., Petrushenko, Y., \& Omelchenko, Y. (2020). The achievement of the country's sustainable development in the conditions of global threats. E3S Web of Conferences, 211. https://doi. org/10.1051/e3sconf/202021101029

41. Sustainable Development Goals Ukraine. Voluntary National Review. (2020). Retrieved from https://sustainabledevelopment.un.org/content/documents/26295VNR_2020_ Ukraine_Report.pdf

42. Svynous, N. I. (2020). Investment support for sustainable development of agricultural enterprises in Ukraine. Visegrad Journal on Bioeconomy and Sustainable Development, 9(2), 72-79. https:// doi.org/10.2478/vjbsd-2020-0014

43. UNDP in Ukraine. (2020). SDG in Ukraine. Retrieved from https:// www.ua.undp.org/content/dam/ ukraine/docs/SDGreports/SDGs_ NationalReportEN_Web.pdf

44. United Nations Sustainable Development. (1992). United Nations Conference on Environment and Development. Agenda 21. Rio de Janeiro, Brazil, 3-14 June 1992. Retrieved from https://sustainabledevelopment.un.org/content/ documents/Agenda21.pdf

45. United Nations, Working Together: Integration, Institutions and the Sustainable Development Goals. World Public Sector Report 2018, UNDESA 2018. https://publicadministration.un.org/publications/ content/PDFs/World\%20Public\%20 Sector\%20Report2018.pdf

46. Yelnikova, Yu. V. (2020). Ranking of regions of Ukraine according to the level of attractiveness for responsible investments. Investments: Practice and Experience, 17-18, 63-68. (In Ukrainian). https://doi.org/10.32702/23066814.2020.17-18.63

47. Yelnikova, Yu.V. (2020). Clustering of countries around the world by the level of their attractiveness for responsible investment. Economy and State, 9, 86-90. (In Ukrainian). https://doi.org/10.32702/23066806.2020.9.86 